\title{
The Implementation of Local Content Curriculum of English for Elementary School in Surakarta, Indonesia
}

\author{
Honest Ummi Kaltsum ${ }^{1 *}$, Wahdan Najib Habiby ${ }^{1}$ \\ ${ }^{1}$ Faculty of Education, Universitas Muhammadiyah Surakarta Surakarta, Indonesia \\ ${ }^{*}$ Corresponding author. Email: huk172@ums.ac.id
}

\begin{abstract}
English for elementary school in Indonesia is regarded as local content curriculum area which mandates that it should include value and local knowledge associated with region in which English curriculum is delivered (Ministerial Decree No.060/U/1993). Considering this decree, this research aims to investigate 1 . The learning devices used by the elementary English teachers regarding to this policy, 2. Teachers' effort in implementing the government policy of English as local content curriculum area. This qualitative study employs case study design to observe and conduct toward elementary English teachers from different education unit background and apply thematic analysis to analyze the data. The findings show that 1 . Elementary English teachers have not yet accommodated the local content in the learning devices such as in the syllabus, lesson plan, media and learning sources, 2 . Teachers only pay a bit attention in implementing this policy. Based on this finding, it will be better if the government provides a kind of strong rule related to local content for elementary school.
\end{abstract}

Keywords: local content, English for elementary school, curriculum policy

\section{INTRODUCTION}

English for elementary school in Indonesia is categorized as a local content curriculum area (Ministerial Decree No.060/U/1993) where in this textbook the content has to be focused on the local elements of the Indonesian people, including the sociocultural elements. This curriculum states that the teaching of English in primary schools can be in the forms of mandatory content and local content [1]. In 1994 curriculum, English was an elective Local Content subject among others, such as Handicraft, Vernacular Languages, and Local Arts, to which these courses need to promote the Indonesian local content of that particular region, namely its particular city or district or state in Indonesia. Indonesian school education policy mandates that the local content should include value and local knowledge associated with region in which English curriculum is delivered (Regulation of the Minister of National Education 2006). The values and local knowledge of local content are categorized into three components: 1) cultural local content, 2) social local content, and 3) physical local content [2]. The implementation of a local content curriculum in the Indonesian education context has started since 1987. The juridical foundation of the implementation of the local content curriculum refers to the Decree of the Minister of Education and Culture No. 0412 / U / 1987. As an elaboration, it was stated in the Decree of the Director General of Primary and Secondary Education Number 173 / -C / Decision / M / 1987. In its later development, the existence of local content is strengthened by the use of local content as one of the contents and structure of the curriculum that must be given at the primary and secondary levels. This is as stated in Article 37 of Law No. 20 of 2003 concerning the National
Education System, which states that elementary and secondary schools must consist of religious education subjects; citizenship education; language education; mathematics education; natural Sciences; Social Sciences; Art and culture; Physical Education and Sports; Skills / Vocational; and local content (National Education System Law No. 2002003 Article 37 paragraph 1).

Furthermore, in the Ministry of National Education Regulation No. 22 of 2006 concerning content standards states that the Education Unit Level curriculum, in addition to containing several subjects, there are also local content subjects that must be imparted at all levels of the education unit. Policies relating to the inclusion of local content subjects in the content standard are based on the fact that Indonesia, which consists of various ethnic groups that have multicultural diversity (customs, ordinances, language, arts, crafts, regional skills) is a characteristic that enriches the value of the life of the Indonesian people, particularly specific to each of the diverse regions in Indonesia.

Reference [3] states that the local content curriculum is an educational program whose content and media (such as visuals) and delivery strategies are linked to the physical environment, social environment, and cultural environment and regional needs. The local content of the physical environment is grouped into four, namely: (1) beaches, (2) lowlands, including watersheds, (3) highlands, (4) mountains or mountains. Meanwhile, the local content of the social environment contains elements or social components that form a network of social interaction and can affect the attitude or actions of a person or group of people. The social components include community institutions and regulations that exist and apply in the area, where students and schools are located, such as villages, neighborhood units, community units, village unit 
cooperatives, community health center, integrated service community and others. Lastly, the local content of the cultural environment discusses cultural elements. The use of the physical, social and cultural environments and tools can be used as media and learning resources. Selective and careful use of these environments and tools can contribute greatly to the improvement of learning processes and outcomes, be it on learning English language subject or any other educational subjects. From the description above, it can be concluded that the impartment of local content within these educational subjects, such as in English language subject, can develop local identities and cultural competencies that are tailored to the characteristics and potential of the region, including the superiority of regions whose material cannot be grouped into existing subjects. Local content is an educational program that is incumbent of content, media, delivery strategies related to the physical environment, social environment, and cultural environment as well as regional needs. Local content contains cultural characteristics, local social and environmental problems. This is in line with what has been written by [2] in which she claims that in the local content curriculum area, students are expected to be able to accommodate their sociocultural aspect of their environment.

Related to the implementation of English as a local content for elementary school, some problems have been raised and identified. First, it is found that teachers' lack of understanding of the concepts of local content, since that the National Standard does not provide any explanation about the background rationale for assigning English as a local content subject in Indonesian elementary schools. Second, putting elementary English as a local content makes it perceived as less important subject [4]. In fact, in regard to elementary English curriculum in Indonesia [5] stated that even after 14 years, the primary English in Indonesia is still not taken seriously due to its position in the curriculum. Since English for elementary education has a limited allocation of time (i.e., 2 x 35-minute weekly lessons), English language learning in elementary education is not seriously prepared by the government. In determining local content, [6]warned that that curriculum developers have not done well at each level of the education unit in preparing students to develop regional potential through the English textbooks. This is characterized through the lack of local content curriculum that develops the potential of each region, and he believes there are still a lot of similarities local content between one school and another, without them being unique to one another especially according to their region. This means that local identities for local content subjects is not clearly seen, especially from the teaching material, i.e., English textbooks. Similarly, Gustine and Sundayana (2008) quoted in [7] stated that based on the overall English [8] books for primary schools that they evaluated, only $30 \%$ are categorized as catering to local content. Categories are seen from the suitability of the material with the curriculum objectives and characteristics of early learning students. The statement above is also supported by [8] who stated that content of textbooks as primary teaching resources were not always appropriate for the mandated curriculum and the students' socio-cultural environments. In this regard [7] states that local educational institutions and local government and local institutions should collaborate in the implementation of local content curriculum starting from planning, implementation, and evaluation which ensures the quality of sustainability of local content and the availability of learning resources. Based on this problems, the researchers are under the impression that the policy of English for elementary school is not seriously prepared by the government. Based on the description above, the researchers analyze the implementation of this policy seen from the teachers' aspect, how does this policy applied by the elementary school English teachers. Related to the previous problem, this study investigates the learning devices applied by elementary English teachers and the way the teachers elaborate the English materials.

\section{METHOD}

The setting of this study is in Surakarta. This is a qualitative study which employs case study design to observe and interview elementary school English teachers from different education unit background and apply thematic analysis to interpret and analyze the data. This case study design is elaborated to disclose the real situation of the implementation of local content of English for elementary school seen from the teachers' aspect. The subject of this study are selected based on purposeful sampling[9] that is two elementary schools English teachers which are from Muhammadiyah Elementary School (MES) 3 and Muhammadiyah Elementary School (MES) 15. This study elaborates two English teachers come from different education unit background. The subject criteria are selected to represent the different learning atmosphere of English language learning in elementary schools in Surakarta. As it had been stated by Bogdan and Biklen [10] that the general design of a case study is represented by a funnel, the researchers scout for possible places and people that might be the subject or the source of the data, find the study location and judge the feasibility of the site or data source for the research purposes. Reference [11] stated that case study is a research approach to investigate thoroughly on a certain people, program, events, activity or process and the study is limited by certain place and time. This case study highlights the implementation of local content curriculum of English for elementary school seen from the teacher aspect and applying deep interview and observation as a method in collecting the data. From the deep interview, stories on what the teachers have been accomplished, how the teachers struggle to conduct this policy can be noted, then analyzed. This will help the government and stakeholders in providing policy and official issues concerning English for elementary school. This statement is similar to (Gerardo \& Contreras, 2000) cited in [12] that giving the PSTs the voice to tell their stories can help educators and other stakeholders understand how those PSTs learn and what struggles they encounter in the absence of appropriate professional support. 


\section{RESULTS AND DISCUSSION}

\subsection{The learning devices used by the elementary English teachers regarding to this policy}

In this topic, the discussion will mainly discuss about the learning devices used in Muhammadiyah Elementary School (MES) 3 and MES 15 Surakarta. First, MES 3 Surakarta. MES 3 Surakarta is a private school under the Muhammadiyah organization. This school uses Islamic Religion as the main handle of its Religious education. English in MES 3 is categorized as local content. Local content, as referred to in the explanation of Law Number 20 Year 2003 concerning the National Education System, is a study material intended to shape students' understanding of the potential in their area. Based on the interviews with teachers, the teachers state that he government policy towards English as a local content is important to be taught to students in harmony with the development of globalization that requires students to master foreign languages, especially English as an international language. In additional there is support from parents of students regarding the existence of local content in English to increase the potential of students in elementary school. This can support the potential of students in cognitive, affective, and psychomotor skills when they have entered a further level.

This school applies the Education Unit Level Curriculum as a curriculum for learning local content in English. The English learning devices used in this elementary school include syllabus, lesson plans, and learning resources. But in the development of learning devices, MES 3 has not accommodated local content in learning English. Teachers are still fixated on textbooks and worksheets in developing learning devices, especially in preparing lesson plans. From this, we can see that the teachers struggle for preparing the best material to accommodate the local content as National guidelines is only available for teaching Grade 4-6 and if schools decide to start teaching it from Grade 1, they have to develop their own curriculum, which is a challenging task. For elementary EFL teachers choosing and developing learning materials are not an easy task, and therefore they need more practical knowledge rather than theoretical knowledge as envisioned by the curriculum. Consequently, most elementary EFL teachers faithfully follow the textbook or student work sheets. Their teaching is simply bookish [13].

In the learning process, English learning activities as local content take place in the classroom and outside the classroom. However, these learning activities are more often done in the classroom with learning material contained in textbooks and worksheets, in addition to that learning has also been done outside the classroom in the form of outing-class by visiting local tours, such as Prambanan Temple to practice speaking with native speakers.

Learning resources used in MES 3 are textbooks written by S.B. Sulaiman and the team published by Yudhistira and the worksheet written by Bambang Hendratmo published by CV Surya Badra. In addition to learning resources, MES
3 the English-Indonesian Dictionary by Amijoyo, the English Dictionary by John Echols, the Ideal EnglishIndonesian Illustrated Dictionary: Grammar and Conversation by Handoko, and the Children Photo Dictionary by Sukarni. Besides dictionaries, teachers use learning media, worksheets and sometimes find references from the internet when there is important material that is not provided in the book. Based on the results of the interview on learning media, it is developed through projects created by students. So students make their own media as a means of learning. For example, students are asked to create traffic signs media. Worksheets that are developed by the teacher are student evaluation sheets which include evaluation materials for daily tests, midterms and final examinations. Based on the above data it can be concluded that MES 3 Surakarta in applying English as a local content does not accommodate the local potential of the Surakarta and teacher occasionally inserts the general local content in Indonesia in certain unstructured materials.

Next, MES 15 Surakarta. MES 15 Surakarta is a school built on gifted land owned by the late Mr. Wiryo Saleh. English lessons at MES 15 are included as the local content. Related to government policy which states that English is a local content, grade 4 teachers of MES 15 Surakarta responded that this is good to apply because English in junior high school is considered as a national exam so that the existence of English since elementary school can help students prepare for next school level. MES 15 Surakarta especially the 4th grade teacher states that the teacher has the learning devices like syllabus, lesson plan, and learning resources. English lesson plans prepared by teachers still use the Education Unit Level Curriculum. Based on interviews, the syllabus and lesson plan developed by the teacher do not accommodate local content. The English learning activities undertaken by the teacher are only carried out in the classroom and are spurred on in textbooks and worksheets.

Learning resources as a support for learning used at MES 15 , especially grade 4 , are worksheets written by Bambang Hendratmo published by CV Surya Badra. At MES 15, students only have a primary learning resource, a worksheet because government's aid does not fund the expenditure of books on local content so students have problems in getting textbooks, one of which concerns the financial limitations of some students so that textbooks are only owned by the teacher. The teacher has reference material as a worksheet reference from the e-book textbook that is personally downloaded, namely the Elementary School English Smart Books for Grades 4, 5, and 6 by Susana which are accessed through academia.edu. In addition, sometimes the teacher uses learning media and the teacher develops a worksheet that is made through a summary of the material. Worksheets that are developed by the teacher are student evaluation sheets which include evaluation materials for daily tests, midterms and final examinations. Based on the above data it can be concluded that MES 15 has not accommodated the local potential of the Surakarta. 


\subsection{Teachers' effort in implementing the government policy of English as local content curriculum area.}

Based on deep interview to English teachers in MES 3 and MES 15 Surakarta which is strengthened by observation, it is found that the elementary school English teachers fully supported the government policy related to English as local content in elementary school despite the lack of supporting teaching and learning devices set by the government. However, to conduct the teaching and learning process, the teachers uses the material provided and sold in the market regardless the lack of local content. The learning devices used by the teachers are textbook and worksheet. These textbooks and worksheets are gotten from the market in which the core material of these textbooks and worksheets do not convey any local content at all. Besides, in developing the syllabus and lesson plan, the teachers also excluded the policy of English as local content. They stated that local content is crucial to teach to children however some learning devices provided do not load the local content but only the light and general topic such as fruit, flowers, animals or daily activities in which in each topics do not touch at all any local content which is tailored to where the material is taught. So overall it can be concluded that MES 3 and MES 15 have not been structured to accommodate the local content of Surakarta.

Some problems faced by the teachers are in line with the study conducted by [5] which stated that the policy of introducing English to our elementary school children has been a wise thought although there are numerous constraints and difficulties we constantly face. Besides, teachers also have difficulties in finding culturally appropriate teaching materials [14]. The imported course books are generally not appropriate to the local Indonesian cultures, while those produced by local publishers do not place emphasis on cultural values and rely too much on superficial content [15]. National guidelines are available for teaching Grade 4-6 and if schools decide to start teaching it from Grade 1, they have to develop their own curriculum, which is a challenging task. Based on this finding supported by others it is clear that the local content for English subject in elementary school is not accommodated by the learning devices set by the teachers since the National Guidelines does not prepare a kind of official and serious management in implementing English for elementary school. The teachers must provide the learning devices by themselves in which it is a kind of challenging task. For elementary EFL teachers choosing and developing learning materials are not an easy task, and therefore they need more practical knowledge rather than theoretical knowledge as envisioned by the curriculum. Consequently, most elementary EFL teachers faithfully follow the textbook or student work sheets. Their teaching is simply bookish [13]. Within the range of competences that a teacher should master, good curriculum design plays a fundamental role to guide instructional action in an intentional, systematic and thoughtful way [16]. It can be said that the government must also provide good curriculum design for elementary school to make the best outcome of learning since curriculum is a set of plans which contains learning objectives, content and learning materials. It is used as a guideline to carry out teachinglearning processes to gain a certain educational objective. This objective covers local charateristics and conditions, also the needs of the students and educational institution [17]. Besides, according to Kaplan and Baldauf (2005), curriculum influences the overall success of language-ineducation policies [18].

\section{CONCLUSION}

Because the English language subject for elementary school is categorized as local content curriculum area, this means the learning devices of this subject should cover about the distinctive aspects of local content of this setting including the social local content, cultural local content and physical local content. It is also assumed that the teacher will support this policy totally by providing the learning devices to accommodate the local content. However, after conducting deep interview strengthened by observation, it is found that first, the learning devices used are lack of local content. Second, when it is seen from the teachers' aspect, it is found that the teachers fully support the government policy, however they face some problems regarding to the learning devices since the National Standard does not provide curriculum with exact guidance and the teachers have to create their own learning devices in which it is a kind of challenging task. This make the teachers use the provided learning devices which do not accommodate any local content at all. The researchers believe that government policy that sets English as a local content has not gone well, seen from the aspect of learning devices used.

Based on the Indonesian government policy about Elementary English Education which clearly stated that Elementary English should be categorized as local content, from the analysis of this research, this is clearly not yet happening. That said, the elementary English education unit should pay attention to the government policy in ensuring the general content of not just Indonesia as a country is represented, but also the local content of the city, district or particular setting in Indonesia is also represented. From the findings of this research, it seems that the government should have to provide such a well-organized curriculum of English for elementary school which includes providing the appropriate learning devices so that the local content can be explored optimally. This will give benefit to young learners social and cultural awareness since the book is not only addressed for the students in studying English, but at the same time for them to also learn their own culture, physics, and society.

\section{ACKNOWLEDGMENT}

This work was supported by the Research Fund provided by LPPM, Universitas Muhammadiyah Surakarta. 
[10] S. K. BOGDEN, C. Robert; BIKLEN, No Title[6] BOGDEN, C. Robert; BIKLEN, Sari Knopp.

Qualitative Research for Education: An Introduction to Theory and Methods, Boston: Ally and Bacon. 1982. .

[1] JULIANSYAH, "Development of English Language Learning Model for Speaking Ability for Elementary School Students (Age 7-9) Based on the Theory of Theme and Rheme," Asian EFL J., vol. Volume 20, no. May, Issue 5, 2018.

[2] N. Triana, "English Education at Elementary School in Japan," 2017.

[3] M. Nasir, "Pengembangan Kurikulum Muatan Lokal Dalam Konteks Pendidikan Islam Di Madrasah," HUNAFA J. Stud. Islam., vol. 10, no. 1, p. 1, 2013.

[4] Iskandar, "Putting English As A Local Content Subject In Primary Schools: Teachers' Belief And Its Impact On Their Teaching Delivery.'

[5] N. Supriyanti, A. Triastuti, and F. Bahasa, “Teaching English as Foreign," pp. 0-49, 2008.

[6] A. BASARI, "No Tit[1] BASARI, Ahmad. Penguatan Kurikulum Muatan Lokal dalam Pembelajaran di Sekolah Dasar. Prosiding Ilmu Pendidikan, 2014, 1.1.le," 2014.

[7] Maryono, “The Implementation of Schools' Policy in the Development of the Local Content Curriculum in Primary Schools in Pacitan, Indonesia," Educ. Res. Rev., vol. 11, no. 8, pp. 891-906, 2016.

[8] A. Faridi, "The Development of Context-Based English Learning Resources for Elementary Schools in Central Java," Excell. High. Educ., vol. 1, no. 1\&2, pp. 23-30, 2010.

[9] CRESWELL, No Title[5] CRESWELL, John. Riset pendidikan: Perencanaan, pelaksanaan, dan evaluasi riset kualitatif \& kuantitatif. Yogyakarta: Pustaka Pelajar, 2015. 2015.
[11] J. W. CRESWELL, CRESWELL, John W. Research design pendekatan kualitatif, kuantitatif, dan mixed. Yogyakarta: Pustaka Pelajar, 2010. Title. .

[12] T. El Masry, "On the Cultivation of Their Community of Practice : A Case Study of EFL Malaysian Pre- Service Teachers On the Cultivation of Their Community of Practice : A Case Study of EFL," vol. 23, no. 4, pp. 952-977, 2018.

[13] A. C. Alwasilah, "Policy On Foreign Language Education In Indonesia,” pp. 1-19, 2013.

[14] I. Iskandar and U. N. Makassar, "Putting English as a Local Content Subject in Primary Schools : Teachers 'Belief and Its Impact on their Teaching Delivery," no. September 2015, 2017.

[15] M. S. Zein, "Elementary English education in Indonesia: Policy developments, current practices, and future prospects," English Today, vol. 33, no. 01, pp. 53-59, Mar. 2017.

[16] D. CAPPERUCCI, “CAPPERUCCI, Davide. English language teaching and learning in Primary School. theoretical and Methodological Perspectives. Studi sulla Formazione, 2017, 20.2: 203-217.," 2017.

[17] I. A. S. Widiastuti, N. N. Padmadewi, and L. P. Artini, "A Study On The Implementation Of English School Based Curriculum In Sma Negeri 5 DenpasaR," vol. 1, 2013.

[18] Y. G. Butler, "Issues in the Assessment and Evaluation of English Language Education at the Elementary School Level : Implications for Policies in South," vol. 6, no. 2, pp. 1-31, 2009. 